Jonace Manyasa

UDK 811.133.1'366.52:378(678)

Dar es Salaam University College of Education, Faculty of Humanities and Social Sciences

Tanzania

jmanyasa@yahoo.fr
DOI: $10.4312 /$ vestnik.11.65-86

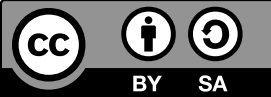

\title{
ANALYSIS OF FRENCH GRAMMATICAL GENDER ERRORS COMMITTED BY LEARNERS IN TANZANIAN UNIVERSITIES
}

Studies on French as a foreign language in Tanzania indicate that learners have difficulties related to the learning of French. Revealing some of the phonological difficulties that learners face when learning French at the university level, Neckemiah (2012:96) gives the following remarks:

" Nous avons, à partir des résultats de l'enquête et de l'analyse de la situation sociolinguistique et du système éducatif de la Tanzanie, constaté que les difficultés de prononciation du français sont dues à la différence entre les systèmes phonologiques du français et celui du swahili et des autres langues bantoues et au manque d'exposition à la langue française ».

Our Translation:

We have, from the findings of the study and the analysis of the sociolinguistic situation and from the Tanzanian education system, established that the pronunciation difficulties in French are due to the difference between French phonological systems and Swahili/other Bantu languages and lack of exposure to French language.

Neckemiah's remarks show that learners of French in Tanzania experience difficulties that arise from the differences that exist between their languages - Kiswahili or ethnic community languages and the target language system (French). Archibald and Libben (1995) contend that learners of a foreign language have a starting point when they start learning, their L1 grammar. During the learning process, one expects learners to master the grammar of the target language. However, learners face problems when trying to learn the grammar of the target language since they sometimes transfer the rules of 
their L1 into the target language, leading to errors. It is important to point out that, apart from the errors that are due to language transfer, learners may also face difficulties when learning the grammatical rules that are inherent in the target language since languages do not necessarily share the same grammatical patterns. According to Perdue (1980), the learning of a second or foreign language entails the making of errors since learners are in a cognitive activity that includes testing hypotheses on the structure of the target language. Errors, therefore, may occur because learners are not fully aware of the grammatical patterns that are inherent in the target language.

Another study by Omary (2002) examined pronunciation problems faced by Tanzanian learners when learning French. The study focused on secondary school students and teachers as well as University of Dar es Salaam students. The findings indicate that some French sounds posed pronunciation problems to Tanzanian learners.

Murekatete (2012) focused on the analysis of French lexical representations by teachers with a goal to examining how French vocabulary is taught in the context of Tanzania. The findings show that French teachers do not put much emphasis on the teaching of French vocabulary, making it impossible for learners to learn this language aspect. These earlier studies focus on phonology and vocabulary, while the current study focuses on French grammatical gender errors.

2 PRESENTATION OF THE RESEARCH CONTEXT

This section presents the research context, focusing on the sociolinguistic situation in Tanzania.

\subsection{The Tanzanian linguistic situation}

Rubagumya (1991) posits that the linguistic situation in Tanzania is triglossic. There are three language clusters that come into play in the context of Tanzania: ethnic community languages, Kiswahili and English. As far as the education system is concerned, Tanzania has two languages as medium of instruction: Kiswahili and English. Other languages are also taught in both private and public schools. These are French and Arabic. At present, there are other foreign languages such as German (at the Goethe Institute), Chinese (at the Confucius Institute) and Turkish (at Feza Schools).

\subsection{Ethnic community languages}

Tanzania has different ethnic community languages, and the number of these has been reported differently by different researchers. For instance, according to Rubagumya (1990), 
there are 120 ethnic community languages, while Maho and Sands (2003) claim there are 126. The most recent survey of the Tanzanian linguistic situation by the Languages of Tanzania Project (2009) found 150 ethnic community languages in the country. Such languages are typically spoken in rural areas and function as medium of communication in a particular ethnic community.

\subsection{Kiswahili and English}

Kiswahili serves as a lingua franca in the context of Tanzania. Therefore, many Tanzanians can speak or communicate in Kiswahili at different levels. It brings together different ethnic community languages in terms of day-to-day communication. Apart from being a lingua franca, Kiswahili in Tanzania has various functions. First, it is the first (L1) or second (L2) language for many Tanzanians. Likewise, it is the national and official language in Tanzania. At present, Kiswahili plays a key role as the language of inter-ethnic trade and job opportunities. For example, it is commonly used in the Democratic Republic of Congo where it was adopted as the language of migrant workers in the mineral-rich Shaba Province (Mazrui and Mazrui, 1998). It is now also one of the official languages that are used in regional integration summits in Africa, and in July 2004 the African Union's Council of Ministers endorsed Kiswahili as one of the official languages of the AU. It was also declared one of the official languages of the Southern African Development Community (SADC) during its $39^{\text {th }}$ Ordinary Summit of Heads of States, held in Dar es Salaam from the $5^{\text {th }}$ to the $18^{\text {th }}$ of August, 2019. English, on the other hand, is a second official language after Kiswahili (Rubagumya 1990). As an official language, it has different functions: the language used in the high court, diplomacy and international trade. Additionally, it is used as a language of instruction at secondary school and the university level. However, in practice it is confined to official usage as it is not spoken by many Tanzanians.

\subsection{French in Tanzania}

In Tanzania, French is a foreign language. The first encounters between French speakers and Kiswahili speakers date back to the 16th century, when Europeans (including the French) arrived in East Africa. These French speakers included explorers (such as Charles Guillain,) and missionaries, especially from the Holy Ghost and White Fathers (Mtavangu 2013). The introduction of French in the Tanzanian educational system dates back to 1958. French was intended to meet communication needs in trade and regional integration between Tanzania and neighbouring countries. Currently, it is an important language because it is used by other members of regional integration bodies of which Tanzania is a member, including the East African Community (EAC) and the Southern 
African Development Community (SADC). Some members of these regional organizations use French as an official language (Burundi, Rwanda, Democratic Republic of Congo, Comoros and Seychelles). Consequently, learning French in Tanzania makes it possible for Tanzanians to interact with people from other countries in Africa. Furthermore, the influx of refugees from neighbouring countries, such as Burundi and the Democratic Republic of Congo, necessitates the teaching and learning of French in Tanzania. Moreover, and irrefutably, the presence of international refugee agencies such as UNHCR (United Nations High Commission for Refugees) has created job opportunities for Tanzanians who speak French.

Given the factors above, the teaching of French in Tanzania is important. The Tanzanian sociolinguistic situation indicates that French does not have the same social privileges as Swahili or English, and the status of French as a foreign language cannot be compared to that of English. Unlike French, English is widely used as a medium of instruction at secondary and tertiary levels of education. This status makes it possible for English learners to get better exposure as compared to French learners. French is mostly confined to the classroom situation, and is taught in selected public secondary schools and some private schools as a compulsory subject in the first two years (Form One and Form Two). It then becomes an optional subject when students enter Form Three. French is also taught in some universities such as the University of Dar es Salaam and in some private primary schools like the International School of Tanganyika.

At the University of Dar es Salaam, French is taught in the following bachelor's degree programs: $\mathrm{BA}^{1}$ with Education, $\mathrm{BED}^{2}$ and BA Language Studies (BALS). At DUCE (a constituent University College of the University of Dar es Salaam), there are two bachelor programs in which French is taught (BA with Education and BED). Students who are enrolled in these programs take French as a major course for three years. Normally, a major course is taught for three hours a week. There are a total of 15 weeks of teaching and evaluation in a semester (with a total of 45 hours). At UDOM, bachelor's programs in which French is taught include the BA in Education, BED and BA French. At Makumira, a bachelor's program with French also includes the BA in Education.

\section{3}

\section{LITERATURE REVIEW}

\subsection{Gender marking in French}

In French, grammatical gender is either masculine or feminine. Guillaume (2010) contends that French native speakers assign grammatical gender using certain indicators such as context, adjective forms, pronouns or structural properties of nouns (including

1 Bachelor of Arts

2 Bachelor of Education 
derivational morphemes). Hellinger and Bussmann (2001) point out that grammatical gender types vary according to a given language. For example, in Latin, German or Russian, all three gender types are present. Languages such as French, Spanish or Italian have lost the neutral grammatical gender. Other languages such as Dutch or Scandinavian languages have other gender aspects, such as the neuter, then another form, which replaces the masculine and the feminine. Thus, grammatical gender is binary or ternary in a given language. Hellinger and Bussmann give the example of the word "sun", whose gender varies according to language, confirming the semantically arbitrary aspect of the grammatical gender: Thus, the word "sun" is grammatically feminine in German, masculine in Greek, in Latin and in Romance languages (such as French: Le soleil/the sun). Arrivé (1997) posits that grammatical gender categorization in French refers to animate and inanimate nouns. According to Corbett (1991), assigning gender in French may be determined by semantic and morphological properties. Corbett posits that assigning grammatical gender in French depends greatly on the form of nouns. For example, in the word éducation (education), the derivational morpheme - tion indicates that the noun is feminine. On the other hand, nouns such as demoiselle (miss), fille (girl) and femme (woman) are feminine in nature, following their semantic properties.

Studies have shown that learners of French as a first language seem to acquire grammatical gender naturally and unconsciously (Tucker, Lambert and Rigault 1977). Observations show that native speakers make gender assignments correctly, even though they do not know why or how they make these choices. On the other hand, non-native speakers, even those who have learned French for a long time (as is the case with the respondents in this study) are consistently incompetent and undecided when it comes to the assigning of grammatical gender. Following this observation, it is important to point out that the learning of grammatical gender in a second or foreign language environment is not the same as in a first language environment, and this process seems to be baffling for native speakers. Thus, although native speakers are highly skilled at making grammatical gender assignments, they are unable to explain this ability. Franceschina (2005) argues that since learners of French as a second or foreign language seem not to acquire grammatical gender naturally and intuitively, there should be learning strategies to enable them to learn grammatical gender more easily.

\subsection{Interlingual errors}

Interlingual errors are generally related to language interference, due to the learners' first language or any previously studied languages. Füsun (2009) contends that when learning a second or foreign language, everyone is influenced positively or negatively by another language. This influence may come from the learner's first language and/or previously acquired languages. Positive influence occurs when the learner's language or languages 
and the target languages are similar in terms of grammatical aspects. On the other hand, negative influence occurs when the learner's language(s) and the target language are different. Selinker (1972) posits that interlingual errors can occur in several language aspects, such as phonology, lexicology and morpho-syntax. This study deals with the morpho-syntactic aspect.

Singleton (1987) discusses the learning of French as a foreign language in the context where there are three source languages. He describes a learner whose transfer to French as a foreign language came more often from his non-native Spanish than English, which was his first language (L1). He examines the source languages' influence on French as a foreign language regarding French beginners who previously acquired Spanish, Irish and Latin. It turns out that Spanish is the most preferred language as a source of influence. In this case, the perception of the learner with regard to the typological proximity between Spanish and French is important. This interpretation is reinforced by retrospective feedback provided by the learner after the completion of a given task. According to Singleton, the general knowledge of the language includes the relationships that are typological and classified according to several grammatical criteria and language patterns. In this regard, knowledge of French, a Romance language, makes it possible to better learn Spanish, a Romance language.

According to Ahukanna et al. (1981), learners of French and English who are native speakers of non-Indo-European languages tend to more spontaneously transfer vocabulary and other language structures of an Indo-European language they know than other languages previously acquired. In this case, the meaning of language transfer depends on the language that has been studied more recently or more frequently used. That is, the most commonly used language tends to affect the less frequently used. These scholars contend that the general examples of language transfer show a greater trend of language transfer from English (L2) to French (L3) rather than the transfer of other ethnic languages. This is also the case of the appearance of the order of the English words in Swedish and German for some Finish learners, according to Ringbom (1987). In another study, Meisel (1983) contends that a learner is typically influenced by the learning of their previous foreign language, and not by their mother tongue, because it is not sufficiently foreign to disturb them.

On the other hand, it has been observed that among bilingual learners of other language, the influence of L1 is greater and leads to more language transfer than L2. This shows evidence that first languages (L1) may also be sources of language transfer, especially when L1 and the language being acquired are typologically close. For example, it has been observed that learners may use their L1 at the lexical and syntactic levels when they acquire another European language as a third language if this is typologically close to their first one (Bartelt 1989; Ringbom 1987; Singh and Carroll 1979). 


\subsection{Intralingual errors}

Öztokat (1993) points out that intralingual errors are those which directly concern the acquisition of the target language. From a cognitive point of view, it is a question of error sources in the target language itself. If the learner is not familiar with the rules of the foreign language that he is learning, he may commit errors based on another form or rule that resembles the already acquired grammatical rules. Lindsay and Norman (1972) consider the wrong generalization of rules to be among the important sources of learners' errors in second or foreign language learning. In this case, the learner creates his own structures of the target language. Thus, the learner, after learning some rules of the target language, generalizes them to other rules that have common characteristics. The learner even creates his own rules when learning the target language.

\subsection{Conceptual framework}

This study was guided by interlanguage theory and the error analysis approach. Error analysis has a long tradition. It was propounded for the first time by the British applied linguist Pit Corder in 1967, and before error analysis emerged, contrastive analysis was the only approach to the study of errors. However, contrastive analysis only focuses on errors that are due to negative transfer from the learner's first language, while error analysis examines all possible sources of errors. While contrastive analysis compares the target language with the source language, error analysis compares the target language with the learner's interlanguage. This is what is called the applied comparative study. Moreover, the possibility of analysing errors without knowing the language is presented as an advantage against analysing errors using the contrastive approach. Thus, error analysis not only deals with errors that are due to language interference, but also errors due to difficulties that are strictly internal to the target language. Such errors appear as a reflection of the level of competence of learners in the language learned at a given time, and the illustration of some general characteristics of the process of foreign language acquisition. In other words, error analysis cannot replace contrastive analysis, but it offers additional solutions that the latter does not bring to light. The interlanguage theory and the error analysis approach are relevant to this study since they are important in addressing the research objectives. With the interlanguage theory, the researcher could have a clear understanding of the cognitive processes that a learner goes through when learning a target language (Selinker 1972). Such processes include language transfer, transfer of training, overgeneralization, strategies of second language learning and strategies of second language communication. Understanding these processes is important, as this enables the researcher to uncover the reasons why learners committed the errors encountered. With regard to the error analysis approach, the researcher analyses the errors using 
the following steps: identification, description, explanation, evaluation and correction of errors (Corder 1981).

\section{$4 \quad$ METHODS}

\subsection{The study population and sample}

A sample of 61 respondents was selected from four institutions. It consisted of first-, second- and third-year students who were studying French as a foreign language in their respective universities in the 2017/2018 academic year: the University of Dar es Salaam (UDSM), the Dar es Salaam University College of Education (DUCE), the University of Dodoma (UDOM) and Makumira University (Arusha). The respondents included in the study were selected using the following criteria: having studied French from Form One to the university level and being willing to participate. The study adopted a purposive sampling procedure (Creswell 2009). Purposive sampling, alternatively known as non-probability sampling, involves the deliberate selection of units of the universe for constituting a representative sample, convenient to the researcher. In this case, the study involved first-, second- and third-year students with a prior knowledge of French since they learned this language at both ordinary and advanced levels of secondary education. We found this type of sampling suitable for this study because we intended to select only those French language learners who have learned this language for a long time, that is, from Form One to the university level. The choice of these learners over others is highly influenced by the need to examine their competence after learning French for a long time. We therefore did not intend to include those students who started learning French at university as a basic course.

\subsection{Study design and approach}

This study is descriptive. It used both quantitative and qualitative approaches. Creswell (2009) contends that quantitative research is used to quantify a given problem by way of generating numerical data or data that can be transformed into statistics. Thus, it is used to quantify attitudes, views and other defined variables and give a generalization of results from a larger population sample. This approach was employed in this study because the researcher wanted to grasp the extent to which grammatical gender errors are quantified. That is, to account for their gravity. On the other hand, a qualitative approach was also used. Creswell (op. cit.) posits that a qualitative approach is appropriate in the analysis of certain phenomena. In this context, the qualitative approach was needed in the analysis of the grammatical gender errors. For example, the use of a qualitative approach in this study is justified in the data collection, whereby the researcher used 
open-ended topics from which learners wrote compositions. In addition, the researcher gave an explanation about the occurrence of the grammatical gender errors that were encountered.

\subsection{Data collection methods}

To collect data, the researcher relied on a corpus of language from learners' written texts on given subject matters (Ellis 1995). The language corpus was derived from the learners' written productions with a focus on the grammatical gender errors. These written productions were produced by 61 respondents in their respective universities.

\subsection{Data analysis}

The data analysis was qualitative and quantitative. For the qualitative data analysis procedures, the proposed study entailed the five successive steps stipulated by Corder (1981), which are identification, description, explanation, evaluation and correction of errors. Identification is the first stage, which must focus on the correct recognition of errors. This stage is purely a linguistic activity since the researcher focuses on judgments of grammar with respect to the target language rules. The description of error is essentially a comparative process. The data to be compared are the incorrect and correct forms. In this respect, the researcher compared French interlanguage to Standard French and highlighted the areas of difference. The explanation of errors is about accounting for why and how errors come about. It is at this stage that an explanation on the causes of errors was sought and given.

\subsection{Ethical issues}

Prior to undertaking the study, the researcher took into consideration all the ethical issues including obtaining informed consent from the institutions and respondents without any pressure being applied. Informed consent is a procedure in which an individual chooses whether to participate in research after being informed of any information that would be likely to influence their decision. In addition, the researcher sought clearance from the University of Dar es Salaam. Once in the field, the researcher clearly explained to the respondents the purpose of the study to clear up any confusion that may have existed. 


\section{$5 \quad$ FINDINGS AND DISCUSSION}

This section discusses the findings in relation to the following objectives: (i) to identify grammatical gender errors, (ii) to account for their sources and (iii) to propose a corrective treatment.

\subsection{Identified grammatical gender errors}

The findings in this study show that the assigning of grammatical gender is a problem to learners in the selected higher learning institutions. They indicate that learners' grammatical gender errors are mainly found in five categories: the wrong use of possessive adjectives, the feminine indefinite article, masculine indefinite article, feminine definite article and masculine definite article.

\subsubsection{Wrong use of possessive adjectives}

\section{Examples:}

(i) *Mon carrière d'enseignement

(ii) Prendre *son responsabilité

(iii) *Ma travail

The examples above indicate that some learners had errors related to the use of possessive adjectives. In French there are different possessive adjectives, used according to person, number and gender. These possessive adjectives include mon/my: used for singular masculine nouns in the first person singular as in "mon père/my father or singular feminine nouns, starting with a vowel or an aspirated $\mathrm{h}$ as in 'mon arme' (my weapon) and mon habitude (my habit). Ma/my: used for singular feminine nouns in the first person singular as in "ma mère/my mother. Mes/my: used for plural nouns in the first person singular as in "mes parents"/my parents. Ton/your: used for singular masculine nouns in the second person singular as in "ton père/your father or singular feminine nouns, starting with a vowel or an aspirated $\mathrm{h}$ as in 'ton école' (your school) and ton habitude (your habit). $T a$ /your: used for singular feminine nouns in the second person singular as in " $t a$ mère/your mother. Tes/your: used for plural nouns in the second person singular masculine and feminine as in "tes parents"/your parents. Son/his/her: used for singular masculine nouns in the third person singular as in "son père/his/her father or singular feminine nouns, starting with a vowel or an aspirated h as in 'son école' (his/her school) and son habitude (his/her habit). Sa/his/her: used for singular feminine nouns in the third person singular as in "sa mère/his/her mother. Ses/his/her: used for plural nouns in the third person singular as in "ses parents"/his/her parents. Notre/our: used for singular masculine and feminine nouns in the first-person plural as in "notre père/our father. Notre mère/our 
mother. Nos/our: used for plural masculine and feminine nouns in the first-person plural as in "nos chaises/our chairs.

Votre/your: used for singular masculine and feminine nouns in the second person singular as in "votre père/your father. Votre mère/your mother. Vos/your: used for plural masculine and feminine nouns in the second person plural as in "vos enfants/your children. Vos filles/your daughters.

Other possessive adjectives include leur(s)/their: used for singular (plural) masculine and feminine nouns in the third person plural as in "leur père/their father. Leurs oncles/their uncles. Leurs tantes/their aunts.

By examining the examples above, we notice different contexts in which respondents wrongly used possessive adjectives.

In (i), the learner uses a masculine possessive adjective mon (my) with a feminine noun carrière (profession) instead of using a feminine possessive adjective ma (my). In (ii), the learner uses a masculine possessive adjective son (his/her) with a feminine noun responsabilité (responsibility) instead of using a feminine possessive adjective $s a$ (his/ her). Finally, in (iii), the learner uses a feminine possessive adjective ma (my) with a masculine noun travail (work) instead of using a masculine form mon (my).

\subsubsection{Wrong use of the feminine indefinite article}

\section{Examples:}
(i) *Une programme
(ii) *Une emploi
(iii) C'est *une mouvement de peuples.
(iv) *Une petite village
(v) Une démocratie est *une système
(vi) *Une bonne gouvernement
(vii) *Une processus

The examples above show that some respondents wrongly used the feminine indefinite article. In French there are two indefinite articles: $u n$ and une.

Thus, indefinite articles form a category of determiners in which one finds all entities that are not known or definite. $U n$ (a) is used for singular masculine nouns as in un garçon (a boy) and une (a) is used for singular feminine nouns as in une fille (a girl)

In (i), the learner uses a feminine indefinite article une (a) with a masculine noun programme (program). The right indefinite article is $u n$ (a). In (ii), the learner uses a feminine indefinite article une, instead of using a masculine indefinite article un since the noun emploi (employment) is a masculine noun. In (iii), the learner uses a feminine indefinite article une, instead of using a masculine indefinite article $u n$. In this context, the noun mouvement (movement) is a masculine noun. In (iv), the learner uses a feminine 
indefinite article une with a masculine noun village (village) instead of using a masculine indefinite article $u n$. Moreover, in (v), the learner uses a feminine indefinite article une with a masculine noun système (system) instead of using a masculine indefinite article. In (vi), the learner uses a feminine indefinite article une with a masculine noun gouvernement (government) instead of using a masculine indefinite article un. Finally, in (vii), the learner uses a feminine indefinite article une to a masculine noun processus (process). The correct indefinite article is $u n$.

\subsubsection{Wrong use of the masculine indefinite article}

\section{Examples:}
(i) *Un personne
(ii) *Un grand chance
(iii) *Un langue étrangère
(iv) *Un clé
(v) *Un embauche

In (i), the learner uses a masculine indefinite article form un (a) instead of using une since the noun personne (person) is feminine. In (ii), the learner uses a masculine indefinite article $u n$ with a feminine noun chance (chance). The learner also uses a masculine adjective form grand (big). In this context, the learner should use a feminine indefinite article une and a feminine adjective form grande (big). In (iii), the learner uses a masculine indefinite article $u n$ instead of using a feminine indefinite article une. The noun langue (language) is a feminine noun. In (iv), the learner uses a masculine indefinite article un instead of using a feminine indefinite article une because clé (key) is a feminine noun. Finally, in (v), the learner uses a masculine indefinite article un with a feminine noun embauche (employment/work) instead of using a feminine indefinite article une.

\subsubsection{Wrong use of the feminine definite article}

\section{Examples:}
(i) *La continent
(ii) *La domaine économique
(iii) *La système
(iv) *La commerce
(v) Dans *la contexte de communication
(vi) *La tourisme
(vii) *La facteur d'emploi

The examples above show that some respondents wrongly used the feminine definite article. Definite determiners indicate that the noun referent is clearly known to both the 
speaker and addressee in a given context. In French, definite determiners are either masculine or feminine, as presented below:

a) Le/the: for singular masculine nouns as in "le soleil" (the sun)

b) La/the: for singular feminine nouns as in "la lune" (the moon)

c) Les/the: for plural feminine and masculine nouns as in "les Tanzaniens" (Tanzanians) or les Tanzaniennes.

In (i), the learner uses a feminine definite article la (the) with a masculine noun continent (continent). The correct definite article is $l e$ (the). Indeed, the same rule applies to (ii), (iii), (iv), (v), (vi) and (vii). In (ii), the learner uses a feminine definite article with a masculine noun domaine (domain). In (iii), the learner uses a feminine definite article with a masculine noun système (system). In (iv), the learner uses a feminine definite article with a masculine noun commerce (commerce). In (v), the learner uses a feminine definite article $l a$ (the) instead of using a masculine definite article $l e$ (the), since the noun context (context) is a masculine noun. In (vi), the learner uses a feminine definite article instead of using a masculine definite article. This is wrong because the noun tourisme (tourism) is a masculine noun. In (vii), the learner uses a feminine definite article with a masculine noun facteur (factor) instead of using a masculine definite article.

\subsubsection{Wrong use of the masculine definite article}

\section{Examples:}
(i) *Le culture
(ii) * Le personne qui étudie la langue française
(iii) *Le route d'Ubungo
(iv) Il donne *le paix
(v) *Le démocratie
(vi) *Le relation
(vii) *Le langue
(viii) *Le chance
(ix) *Le compagnie qui se trouve dans l'Afrique
(x) *Le Belgique

The examples above indicate that the respondents also wrongly used the masculine definite article. In (i), the learner uses a masculine definite article form le (the) instead of la (the), which is relevant in this context since the noun to be qualified culture (culture) is a feminine noun. The same thing applies to the other examples. In (ii), the learner uses a masculine definite article with a feminine noun personne (person) instead of using a feminine definite article. In (iii), the learner uses a masculine definite article with a feminine noun route (way) instead of using a feminine definite article. In (iv), the learner uses a 
masculine definite article with a feminine noun paix (peace) instead of using a feminine definite article. In (v), the noun démocratie (democracy) is a feminine noun. In this case, the use of the masculine definite article is wrong. In (vi), the learner uses a masculine definite article instead of using a feminine definite article with the noun relation (relationship). In (vii), the learner uses a masculine definite article instead of using a feminine definite article with the noun langue (language). In (viii), the use of a masculine definite article le (the) with a feminine noun chance (chance) is wrong. In (ix), the learner uses a masculine definite article with a feminine noun compagnie (company). Finally, in (x), the learner uses a masculine definite article le (the) with a feminine country name Belgique (Belgium). The right definite article is la (the).

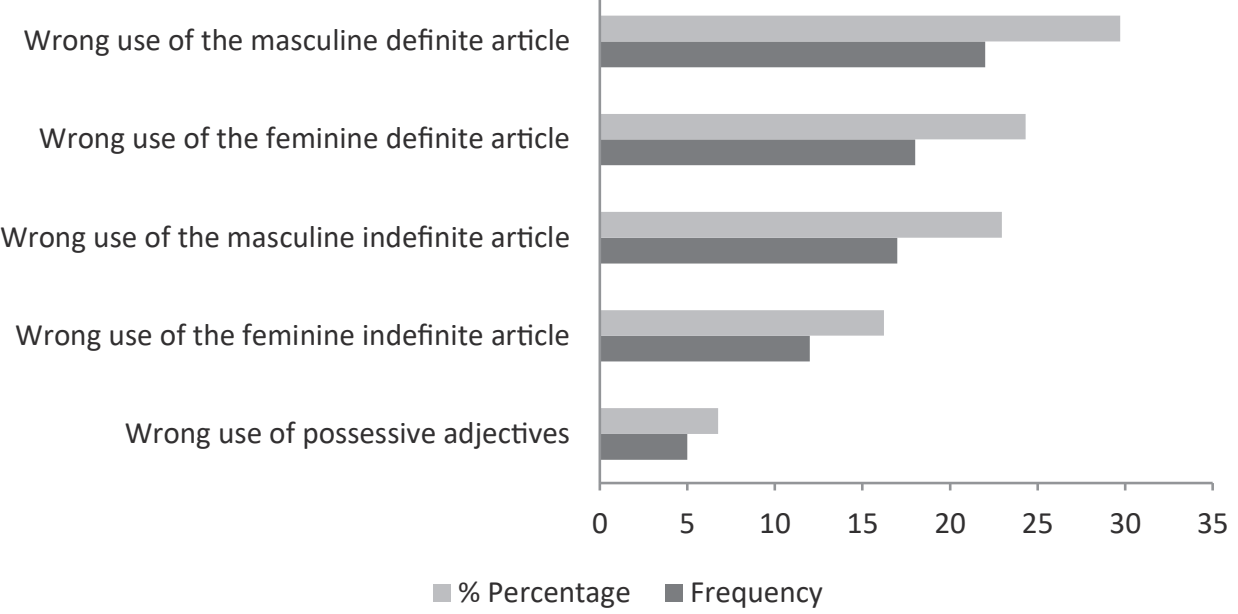

Figure 1. Frequency and percentage distribution of grammatical gender errors

The findings presented above (Figure 1) show that errors with regard to the wrong use of the masculine definite article accounted for $29.73 \%$ of the total, with a frequency of 22 . The findings further show that $24.32 \%$ of all errors were for the wrong use of the feminine definite article, with a frequency of 18 . Errors on the wrong use of the masculine indefinite article accounted for $22.97 \%$ of the total with a frequency of 17 . Errors on the wrong use of the feminine indefinite article took up $16.22 \%$ of the total, with a frequency of 12. Finally, errors on the wrong use of possessive adjectives accounted for $6.76 \%$ of the total, with a frequency of 5 .

\section{$5.2 \quad$ Sources of errors}

Unlike other studies that have looked into assigning grammatical gender in French (Alagra 2015; Gareau 2008), this work included learners whose previously acquired languages do 
not have grammatical gender markers, as is the case with French. Indeed, learners in the context of Tanzania may face difficulties when learning aspects of grammatical gender in French because this does not exist in Kiswahili or other ethnic community languages spoken by Tanzanians. While French uses determiners (definite or indefinite) to qualify nouns, Kiswahili and other ethnic community languages do not use any determiners, as shown in the following examples:

\section{Examples:}

$\begin{array}{lll}\text { 1. } \mathrm{Ni} \text { na kula } \emptyset^{3} \text { ndizi } & \text { [Kiswahili] } \\ 1 \mathrm{SG}^{4} \mathrm{PRES}^{5} \text { eat banana } & \\ \text { 'I am eating banana.' } & \\ \text { 2. Je mange une } \text { banane } & \text { [French] } \\ \text { I eat INDF } & \text { a banana } & \\ \text { 'I am eating a banana.' } & \end{array}$

Therefore, the noun phrases are different, as presented below?

(a)

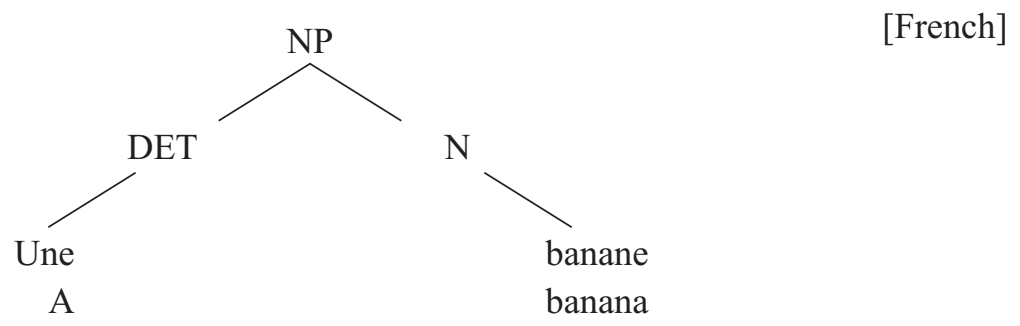

(b)

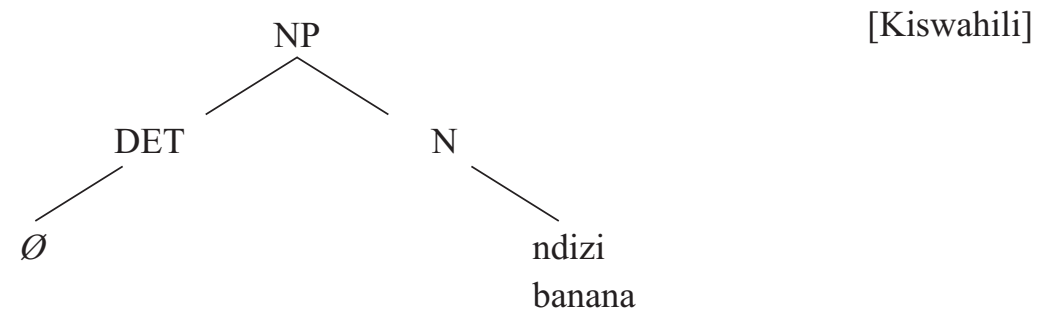

\footnotetext{
3 We use the symbol $\varnothing$ to denote the absence of an element.

4 Singular

5 Present

6 Indefinite

7 NP (noun phrase), DET (determiner), N (noun), 3SG (third person singular), PST (past), AUX (auxiliary), PP (Past Participle), INDF (indefinite) and 1PL (first person plural).
} 
3. A ka gula $\varnothing \underline{\text { sulußali }}$ 3SG PST buy pair of trousers

[Sukuma] 'He/she bought a pair of trousers.'

4. Il/elle a acheté un pantalon [French] $\mathrm{He} / \mathrm{she}$ AUX has PP bought INDF a pair of trousers 'He/she bought a pair of trousers.'

\section{Noun phrases:}

(c)

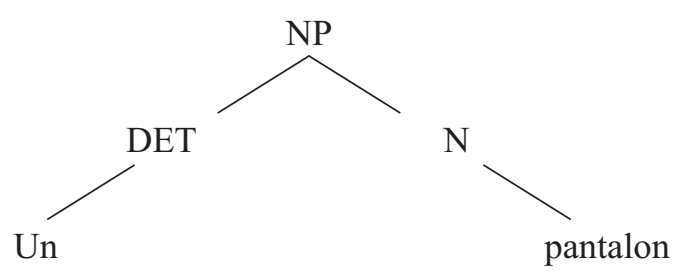

[French]

A pair of trousers

(d)

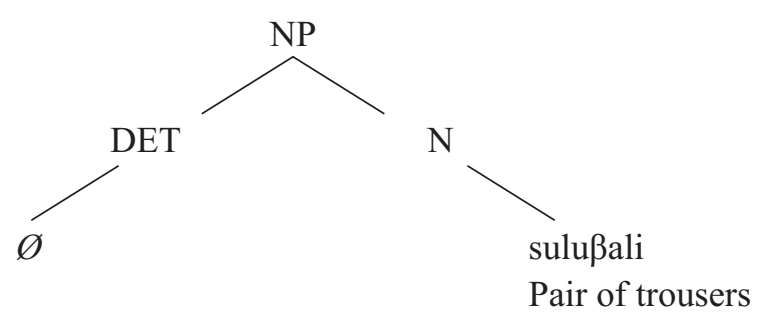

[Sukuma]

5. $\mathrm{Tu}$ li chukua

$\varnothing \underline{\text { kiti }}$ 1PL PST take a chair

[Kiswahili]

'We took a chair.'

6. Nous avons pris une chaise

[French]

We AUX have PP took INDFa chair

'We took a chair.'

Noun phrases:

(e)

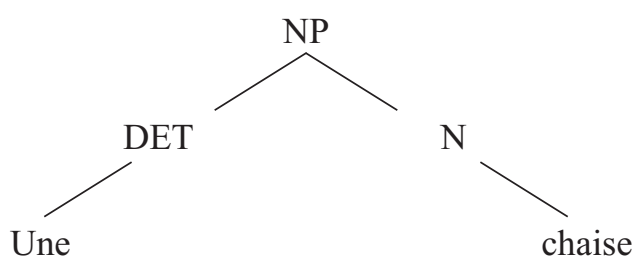

[French]

A chair 
(f)
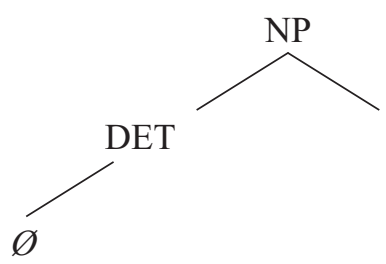

[Swahili]

Indeed, the NP formation rules above apply in (7), (9) and (11) where noun phrases in learners' languages do not require the attachment of articles.

7. Na la guze imodoka

[Hangaza] $1 \mathrm{SG}$ PST buy car 'I bought a car.'

8. $J^{\prime}$ ai acheté $\underline{\text { une }}$ voiture

I AUX have PP bought INDF a car 'I bought a car.'

9. Nda la guze imodoka 1SG PST buy car 'I bought a car.'

10. $J^{\prime}$ ai acheté $\underline{\text { une voiture }}$ [French] I AUX have PP bought INDF a car 'I bought a car.'

11. N guzire emotoka [Lunyambo] 1SG PAST buy car 'I bought a car.'
12. $J^{\prime} \quad a i$ acheté une voiture I AUX have PP bought INDFa car 'I bought a car.'

Moreover, Kiswahili, the language commonly used by our respondents, also does not make a grammatical gender distinction in the use of possessive adjectives, since this distinction is not made for nouns, as shown in the following examples:
13. Hii ni kalamu yake This is pen his/her 'This is his/her pen' [Kiswahili]
14. $C^{\prime}$ est son stylo
This is his/her pen
'This is his/her pen' 


$\begin{array}{ll}\text { 15. } C^{\prime} \text { est son père } & \text { [French] } \\ \text { This is his/her father } & \\ \text { 'This is his/her father' } & \\ \text { 16. } C \text { ' est sa mère } & \text { [French] } \\ \text { This is his/her mother } & \\ \text { 'This is his/her mother' } & \end{array}$

The examples above show that there is a difference between Kiswahili and French when it comes to the use of possessive adjectives. By examining these, we find that in the third person singular Kiswahili uses only one form, 'yake' (his/her), while French uses two, son and $s a$ (his/her). The same applies to other forms such as 'yangu' (my), which is presented by two forms in French ( $\mathrm{mon} / \mathrm{ma}$ ), and 'yako' (your), which is also presented by two forms in French (ton/ta). As a result, this may be confusing to Kiswahili learners of French because gender assignment requires learners to differentiate between masculine and feminine nouns. Since such aspects do not exist in Kiswahili, some learners end up with false assumptions on noun gender, and this eventually leads to grammatical gender errors.

The findings in this study thus suggest that learners' errors are intralingual, and directly concern the acquisition of the target language. These findings imply that learners are not familiar with the rules of the foreign language, and may be due to a defective or partial learning of the target language (French).

\subsection{Corrective treatment}

Difficulties pertaining to grammatical gender can only be minimized through rigorous practice of the target language (French, in this context). Since these errors may be due to a defective or partial learning of the target language, we recommend that suitable strategies be adopted that may enable learners to internalize grammatical gender in French. We therefore recommend that the teacher should first use morphological clues to enable learners to identify nouns that are masculine or feminine in French, such as using suffixes like -ment/-ation.

Moreover, for nouns whose grammatical gender cannot be determined morphologically, different texts can be used to familiarize learners with grammatical gender in French. Through continued reading, learners can then be able to associate grammatical gender markers (determiners, possessives and demonstratives) with noun forms. Finally, the teacher should correct learners' errors on grammatical gender and provide different exercises on this subject in French. 
In this paper, we attempted an analysis of the grammatical gender errors in French. The researcher chose to focus on this grammatical aspect since it is an important aspect in the mastery of French as a foreign language. Indeed, failure to assign grammatical gender in French was found to be a problem among learners in the selected higher learning institutions in Tanzania. The paper went further to examine the causes of the grammatical gender errors. The findings indicated that learners in the context of Tanzania had grammatical gender errors in French due to intralingual sources. That is, these errors directly concern the acquisition of the target language. This implies that learners are not familiar with the rules of the target language (French). Consequently, lack of familiarization with French grammatical gender aspects leads to the wrong assigning of grammatical gender elements. The paper went further to suggest strategies that can be used by French language teachers so as to assist learners with such problems.

\section{BIBLIOGRAPHY}

AHUKANNA, Joshua/Nancy LUND/Ronald GENTILE (1981) Inter- and intra-lingual interference effects in learning a third language. Modern Language Journal, $\mathrm{n}^{\circ} 65$, $281-287$.

ALAGRA, Aziz (2015) Contribution à une étude des dysfonctionnements morphosyntaxiques en français chez un groupe d'enseignants et d'étudiants yéménites. Unpublished $\mathrm{PhD}$ thesis. Univ. Cergy-Pontoise.

ARCHIBALD, John/Gary LIBBEN (1995) Research Perspectives on Second Language Acquisition. Toronto (Mississauga): Copp Clark Ltd.

ARRIVE, Michel (1997) Coup d'œil sur les conceptions du genre grammatical. Comptes rendus des séances de l'Académie des Inscriptions et Belles-Lettres 141.1, 81-96.

BARTELT, Guillermo (1989) The interaction of multilingual constraints. H. W. Dechert and M. Raupach (eds.), Interlingual processes. Tubingen: Günter Narr Verlag, 151-177.

Grammaire Larousse du français contemporain. Paris: Larousse, 1994.

CORBETT, Greville (1991) Gender. Cambridge: Cambridge University Press.

CORDER, Stephen Pit (1967) The significance of learners' errors. J. C. Richards (ed.), Error Analysis: Perspectives on Second Language Acquisition. London: Longman.

CORDER, Stephen Pit (1981) Error analysis and interlanguage. Oxford: Oxford University Press.

CRESWELL, John W. (2009) Research Design. Thousand Oaks, CA, US: Sage Publications, Inc. 
FRANCESCHINA, Florencia (2005) Fossilized second language grammars: The acquisition of grammatical gender. Amsterdam/Philadelphia: John Benjamins.

FÜSUN, Şaraç (2009) Interférences lexicales entre deux langues étrangères. Anglais et français. Synergies Turquie, ${ }^{\circ} 2,179-184$.

GAREAU, Frédéric (2008) L'assignation du genre grammatical en français langue seconde: transfert ou terminaisons des noms? Unpublished Master's Thesis. Montreal: Université de Québec à Montréal.

GUILLAUME, Jeanmaire (2010) L'identification du genre grammatical en français. Langue française, vol. 42, $\mathrm{n}^{\circ}$ 168, 71-86.

HELLINGER, Marlis/Bussmann HADUMOD (2001) Gender across languages. Amsterdam/Philadelphia: John Benjamins.

LANGUAGES OF TANZANIA PROJECT (2009) Atlasi ya Lugha za Tanzania. Dar es Salaam: Mradi wa Lugha za Tanzania, Chuo Kikuu cha Dar es Salaam.

LINDSAY, Peter. H./Donald A. NORMAN (1972) Human Information Processing: An Introduction to Psychology. New York: Academic Press.

MAHO, Jouni F./Bonny SANDS (2003) The languages of Tanzania: a bibliography. Göteborg: Acta Universitatis Gothoburgensis.

MAZRUI, Ali A./Alamin M. MAZRUI (1998) The Power of Babel: Language and Governance in the African Experience. Chicago: University of Chicago Press.

MEISEL, Jürgen (1983) Transfer as a Second Language Strategy. Language and Communication, $\mathrm{n}^{\circ} 3,11-46$.

MTAVANGU, Norbert (2013) La contribution des Français à l'etude du Swahili: le cas de Charles Sacleux (1856-1943). Unpublished PhD Thesis. Paris: INALCO-PARIS - LANGUES.

MUREKATETE, Jeanne (2012) Représentations du lexique par les formateurs et les enseignants en vue de son enseignement : cas de la Tanzanie. Unpublished Master Thesis. Grenoble: Université Stendhal, Grenoble 3.

NECKEMIAH, Nelius (2012) L'amélioration de la compétence phonologique des enseignants de français du secondaire en Tanzanie. Unpublished Master Thesis. Grenoble: Université Stendhal, Grenoble 3.

OMARY, Shan (2002) Pronunciation Problems that Tanzanians learners encounter in learning French. Unpublished Master Thesis. Dar es Salaam: University of Dar es Salaam.

ÖZTOKAT, N. (1993) Analyse des erreurs/analyse contrastive. Grammaire et Didactique des langues, Eskişehir, Anadolu Üniversitesi yayın, $\mathrm{n}^{\circ}$ 590, 66-76.

PERDUE, Clive (1980) L'analyse des erreurs : un bilan pratique. Langages 57, 87-94.

RIEGEL, Martin/Jean-Christophe PELLAT/René RIOUL (2006) Grammaire méthodique du Français. Paris: Quadriage/PUF.

RINGBOM, Haykan (1987) The role of first language in foreign language acquisition. Clevedon: Multilingual Matters. 
RUBAGUMYA, C. M. (1990) Language in education in Africa: a Tanzanian perspective. Clevedon, Avon: Multilingual Matters.

RUBAGUMYA, C. M. (1991) Language promotion for educational purposes: the example of Tanzania. International review of education 37/1, 67-87.

SELINKER, Larry (1972) Interlanguage. International Review of Applied Linguistics 10, 209-241.

SELINKER, Larry (1975) The interlanguage hypothesis extended to Children. Language Learning 25 (1), 139-152.

SINGH, Rita/Susanne CARROLL (1979) LI, L2 and L3. Indian Journal of applied Linguistics, $\mathrm{n}^{\circ} 5,51-63$.

SINGLETON, David (1987) The fall and rise of language transfer. J. Coleman and R. Towell (eds.), The Advanced Language Learner. London: CILT.

TUCKER, Richard D./William E. LAMBERT/André A. RIGAULT (1977) The French speaker's skill with grammatical gender: An example of rule-governed behaviour. The Hague: Mouton.

\section{POVZETEK}

\section{Analiza napak tanzanijskih študentov pri določanju slovničnega spola v francoščini}

Namen prispevka je analiza napak študentov pri določanju slovničnega spola $\mathrm{v}$ francoščini. $\mathrm{V}$ raziskavo so bili vključeni študenti, ki se francoščino učijo kot tuji jezik, obiskujejo pa eno od naslednjih tanzanijskih univerz: Univerzo v Dar es Salaamu (UDSM), Univerzo v Dodomi (UDOM), Visoko šolo za izobraževanje v Dar es Salaamu (DUCE) in Univerzo Makumira. Cilj prispevka je (i) prepoznati napake študentov pri določanju slovničnega spola, (ii) pojasniti vzroke zanje in (iii) predlagati ukrepe za njihovo odpravo. V raziskavo smo vključili 61 respondentov, katerih pisne sestavke v francoščini smo zbrali v korpusu. Raziskovalno delo smo zasnovali na metodi analize napak in na teoriji vmesnega jezika. Podatke smo analizirali kvantitativno in kvalitativno. Rezultati analize so pokazali, da študenti slovnični spol napačno določajo pri rabi določnega člena za moški spol (29,73 \%), pri rabi določnega člena za ženski spol (24,32 \%), pri rabi nedoločnega člena za moški spol (22,97 \%), pri rabi nedoločnega člena za ženski spol $(16,22 \%)$ in pri rabi svojilnih pridevnikov (6,76 \%). Izsledki raziskave kažejo, da tanzanijski študenti, ki se francoščino učijo kot tuji jezik, pri učenju jezikov potrebujejo pomoč. V prispevku so zato predstavljene tudi strategije, ki bi učitelje usmerjale pri nadaljnjem pedagoškem delu na tem področju.

Ključne besede: analiza napak, vmesni jezik, slovnični spol, tuji jezik, ciljni jezik 


\begin{abstract}
This paper analyses the grammatical gender errors committed by learners of French as a foreign language in four Tanzanian universities: UDSM, UDOM, DUCE and Makumira (University of Dar es Salaam, University of Dodoma, Dar es Salaam University College of Education and Makumira University). The paper has three specific objectives: (i) to identify grammatical gender errors, (ii) to account for their sources and (iii) to propose a corrective treatment. The study included a total of 61 respondents. The data was collected through learners' written texts in French from which a corpus was developed. The study was guided by the error analysis approach and interlanguage theory. The data was analysed qualitatively and quantitatively. The findings show that grammatical gender errors were found with regard to the masculine definite article (29.73\%), the feminine definite article (24.32\%), the masculine indefinite article $(22.97 \%)$, the feminine indefinite article $(16.22 \%)$ and possessive adjectives $(6.76 \%)$. These findings show there is a need to help learners of French as a foreign language in the context of Tanzania using the recommended strategies.
\end{abstract}

Keywords: error analysis, interlanguage, grammatical gender, foreign language, target language 